\title{
Behaviors of nitrogen, iron and sulfur compounds in contaminated marine sediment
}

\author{
Md Akhte Khirul ${ }^{1}$, Daechul Cho ${ }^{2}$, Sung-Hyun Kwon ${ }^{3^{\dagger}}$ \\ ${ }^{1}$ Department of Ocean System Engineering, College of Marine Science, Gyeongsang National University, Tongyeong 53064, Republic of Korea \\ ${ }^{2}$ Department of Energy and Environmental Engineering, Soonchunhyang University, Asan 31538, Republic of Korea \\ ${ }^{3}$ Department of Marine Environmental Engineering, College of Marine Science, Engineering Research Institute (ERI), Gyeongsang National University, \\ Tongyeong 53064, Republic of Korea
}

\begin{abstract}
The marine sediment sustains from the anoxic condition due to increased nutrients of external sources. The nutrients are liberated from the sediment, which acts as an internal source. In hypoxic environments, anaerobic respiration results in the formation of several reduced matters, such as $\mathrm{N}_{2}$ and $\mathrm{NH}_{4}{ }^{+}, \mathrm{N}_{2} \mathrm{O}, \mathrm{Fe}^{2+}, \mathrm{H}_{2} \mathrm{~S}$, etc. The experimental results have shown that nitrogen and sulfur played an influential, notable role in this biogeochemical cycle with expected chemical reductions and a 'diffusive' release of present nutrient components trapped in pore water inside sediment toward the bulk water. Nitate/ammonium, sulfate/sulfides, and ferrous/ferric irons are found to be the key players in these sediment-waters mutual interactions. Organonitrogen and nitrate in the sediment were likely to be converted to a form of ammonium. Reductive nitrogen is called dissimilatory nitrate reduction to ammonium and denitrification. The steady accumulation in the sediment and surplus increases in the overlying waters of ammonium strongly support this hypothesis as well as a diffusive action of the involved chemical species. Sulfate would serve as an essential electron acceptor so as to form acid volatile sulfides in present of $\mathrm{Fe}^{3+}$, which ended up as the $\mathrm{Fe}^{2+}$ positively with an aid of the residential microbial community.
\end{abstract}

Keywords: Denitrification, Eutrophication, Hypoxia, Nitrogen release, Nutrient

\section{Introduction}

The explosive growth of resource uses and related population over the world lets us focus on marine resources and the oceanic environment $[1,2]$. Subsequently, those growths have accelerated water and terrestrial pollution. Especially, marine eutrophication has been a big concern in this context due to the rises of industrial wastewater, agricultural/livestock waste, aquaculture activities (e.g., fish and oyster farm) [3, 4]. As a result, input nutrients containing phosphorus, nitrogen and all the organic matter accumulate in the sediment of coastal areas ultimately to result in serious algal blooms in the marine environment $[5,6]$. Nitrogen is one of the most crucial factors of marine eutrophication as a major component for most of the aquatic lives. In general, the coastal area in Korea has a lot of fish and oyster farms, therefore, may confront eutrophication problems due to the direct supply of fish food and effective microbial activation in the sediment. Several coastal regions in South Korea have been suffered from coastal hypoxia caused by eutrophication, in addition to the effects of the artificial structures, such as cages [7, 8]. These cages are generally located from $100 \mathrm{~m}$ to $1.5 \mathrm{~km}$ offshore. In most of open sea cage system in the coast, high nutrients loading generated from feed waste and biotic excretion is directly discharged into the environment. As a result, coastal eutrophication and the presence of artificial structures have involved severe deoxygenation in the coastal areas. In addition, coastal eutrophication is regarded as a serious environmental and social problem that needs to be resolved.

Most often the increase of nutrients loads to coastal waters and sediment are the main cause of eutrophication-associated hypoxia. The consequent hypoxia can demolish the benthos and converted the flow of energy in the food chain downward instead of upward, thus feeding microbes in sediment [9]. Simultaneously, the pursuant hypoxia-induced release of nutrients such as phosphorus and nitrogen from deposited organic matter can be substantial and hold
This is an Open Access article distributed under the terms of the Creative Commons Attribution Non-Commercial License (http://creativecommons.org/licenses/by-nc/3.0/) which permits unrestricted non-commercial use, distribution, and reproduction in any medium, provided the original work is properly cited.

Copyright (C) 2020 Korean Society of Environmental Engineers
Received October 15, 2018 Accepted April 22, 2019

${ }^{\dagger}$ Corresponding author

Email: shkwon@gnu.ac.kr

Tel: +82-55-772-9132 Fax: +82-55-772-9139

ORCID: 0000-0001-5803-2003 
down the tainted consequences of external loading [10, 11]. Thermodynamically, oxygen is the most favorable electron acceptor, but the oxygen depletion in the sediment may contribute to liberate nitrogen from sediment into the water [12]. So increased nitrogen concentration and algal blooms conduct to more intense anoxia and there is a mutual prolonged effect between these processes [13]. Hypoxia can also enhance the release of nutrients from organic compounds in the sediment as ammonium is released from organic compounds by bacterial degradation [14-16]. Under anaerobic and reducing conditions undesirable greenhouse or malodorous gases are produced such as methane $\left(\mathrm{CH}_{4}\right)$ and hydrogen sulfide $\left(\mathrm{H}_{2} \mathrm{~S}\right)$ [17]. Moreover, $\mathrm{H}_{2} \mathrm{~S}$ is formed in organically enriched sediment through the sulfate reduction by sulfate-reducing bacteria under anoxic condition [18]. $\mathrm{H}_{2} \mathrm{~S}$ is highly toxic to living organisms and when it is oxidized, oxygen is used up. Generally speaking, acid volatile sulfide (AVS; not only $\mathrm{H}_{2} \mathrm{~S}$ but also including different sulfur compounds), the eutrophication matter suggests that the excess nutrients input enshroud the self-purify ability of water bodies, thereby changing the characteristics of the ecosystem and leading to phytoplankton blooms [19-21]. Over time, these nutrients could also augment themselves in the sediment and make it possible that an internal load is recycled back into the overlying waters under different environmental conditions [22].

The processes of nutrients across the sediment-water interface are of consideration in understanding the impacts of the chemical composition and the trophic level of aquatic systems, particularly, in coastal marine environments [23]. The nutrients and organic matter concentration in the overlying water of marine environments, which originates from sediment, are regarded as a major component of the internal source. Such releases from bottom sediment may have a significant impact on water quality and may result in continued eutrophication, hence the degree of eutrophication should be determined, and the causation of eutrophication should be diagnosed in the process of eutrophication management, which will be helpful to acquire an apt plan and management [24].

The main purpose of this study was to investigate mutual interactions between sulfate and $\mathrm{Fe}^{3+}$ reduction as well as the production of acid volatile sulfide (e.g., $\mathrm{H}_{2} \mathrm{~S}$ and $\mathrm{FeS}$ ) and ferrous iron $\left(\mathrm{Fe}^{2+}\right)$ in the sediment, served as electron donors for dissimilatory nitrate reduction to ammonium (DNRA). Another goal is to find the roles of the electron donors in nitrogen release from organically-enriched sediment into the water body under a certain environmental condition. Experiments were conducted in a sediment-water basin, simulating the aquatic environment that we are interested in. This study will provide helpful information for the practice of nitrogen release estimation and determine the direction of future studies of coastal eutrophication.

\section{Materials and Methods}

\subsection{Sample Collection and Study Area}

Marine water and sediment samples were collected in the city of Tongyeong ( $\left.34^{\circ} 50^{\prime} 28.5^{\prime \prime} \mathrm{N} 128^{\circ} 28^{\prime} 16.4^{\prime \prime} \mathrm{E}\right)$, in the southeast coast of South Korea. The sampling site was characterized by odoriferous sediment and water due to external pollution sources such as waste dumping through a pipeline and fishing activities particularly by aquaculture activities (e.g., fish and oyster farm). Sediment samples were collected from around $10 \mathrm{~m}$ to $12 \mathrm{~m}$ below of water level using a boat through a stainless steel grab sampler at a depth of $0-20 \mathrm{~cm}$. And then they were quickly packed in airtight cleaned polythene bags and were transported to the laboratory for storage at $-20^{\circ} \mathrm{C}$ until analyses. The sampler was cleaned with distilled water before use to eschew unnecessary contamination. A sufficient amount of seawater was collected from the same site as samples at a depth of $0.5 \mathrm{~m}$ to $1.0 \mathrm{~m}$ by a water sampler. All samples were homogenized before their quantification/analyses.

\subsection{Laboratory Setup for Incubation}

For experiments, a sediment sample of $300 \mathrm{~g}$ was prepared in a 2-L graduated basin. One liter of filtered seawater was added carefully into the basin in order to avoid disturbing the sediment. Five replicate basins were established for the experiments of the $20 \mathrm{~d}$ incubation period. All basins were covered with aluminum foil and were placed in the incubator at $22^{\circ} \mathrm{C}$. The temperature was fixed as the same condition with situ areas that might ensure steady microbial activity. A time interval of $12 \mathrm{~h}$ light and 12 $\mathrm{h}$ darkness in a day was maintained through the entire incubation period. Samples were taken from each individual basin for analysis on the days of $0,5,10,15$ and 20 .

\subsection{Analyses of Physicochemical Characteristics and Chemical Analysis}

Before measuring the physicochemical parameters, the overlying water \& sediment were separated from the basin and the sediment was homogenized. The parameters of seawater and sediment, including oxidation-reduction potential (ORP) and $\mathrm{pH}$ were measured at the basin using the multi-parameter meter (Orion 3 star, USA), additionally DO with temperature in the overlying water was measured by DO meter (YSI 550A, USA). The AVS was measured by the sulfide detection tube (Detector Tube No. $201 \mathrm{H}$; measuring range 0.02-0.20 mg, GASTEC, Japan) as follows: $2 \mathrm{~g}$ of a sediment sample was mixed with $2 \mathrm{~mL}$ concentrated sulfuric acid, which was continuously pumped into the tube until the tube color changed [25].

The water samples were carefully withdrawn from the basins and were filtered through a glass microfiber filter paper $(\mathrm{GF} / \mathrm{C}$, What man, UK) before sampling. The sediment samples were collected to three centrifuge tube on an average 65-70 gm from basin then centrifuged at 2,000 rpm for $20 \mathrm{~min}$ to collect around 10 $\mathrm{mL}$ of supernatant pore water. This pore water was used as the diluted sample within the detective range. The chemical oxygen demand (COD) was determined by the oxidizing agent of potassium permanganate followed by the iodometric titration method which denoted the standardized analytic procedure. The concentration of ammonium nitrogen $\left(\mathrm{NH}_{4}{ }^{+}-\mathrm{N}\right)$ was determined by the indophenol blue method, total nitrogen (T-N) was measured by oxidizing sample with potassium persulfate, nitrate $\left(\mathrm{NO}_{3}^{-}-\mathrm{N}\right)$ and nitrite $\left(\mathrm{NO}_{2}^{-}-\mathrm{N}\right)$ concentration was measured by through a cadmium-copper(Cd-Cu) column reduction $\mathrm{N}$-(1-naphthyl)- ethylenediamine adsorption spectrophotometry respectively according to standard methods for the examination of marine environmental pollution [25]. Sulfate 
was determined by spectrophotometry turbidimetric method using barium sulfate. Fe was determined spectrophotometrically using reducing ferrozine reagent assay after extraction [26, 27]. The concentration of extractable $\mathrm{Fe}^{3+}$ was determined by the difference between total extractable $\mathrm{Fe}$ and $\mathrm{Fe}^{2+}$. The concentration of all spectroscopic analyses was done by UV Mini- 1,240 spectrophotometer (Shimadzu Corporation, Kyoto, Japan). For all samples, sediment and overlying water were analyzed three times and the data were used on average.

\subsection{Nutrients Release Experiments}

Nutrients releases at the sediment and water interface in the basin were investigated in terms of those rates. Nutrients release rates were determined according to the method of Hieltjes and Lijklema [28] proposed. The rates were calculated under the assumption that the concentrations of species $i$ depend only on flow-out, flow-in and horizontal surface area over the sediment and with the material balance over the reactor [29]. In order to achieve the nutrients release rate, the calculation was done by the following equation:

$$
r=\frac{\left[V\left(C_{n}-C_{o}\right)+\sum V_{n}\left(C_{n-1}-C_{a}\right)\right]}{A_{t}}
$$

Where,

$r$ is releases rate $\left(\mathrm{mg} / \mathrm{m}^{2} / \mathrm{d}\right)$.

$V$ is the volume of overlying water $\left(0.001 \mathrm{~m}^{3}\right.$ in this study). $C_{n}$ is the concentration of nutrient got the $\mathrm{n}^{\text {th }}$ time $(\mathrm{mg} / \mathrm{L})$.

$C_{0}$ is the initial concentration of nutrients $(\mathrm{mg} / \mathrm{L})$.

$V_{n}$ is the sampling water volume each time $\left(\mathrm{m}^{3}\right)$.

$C_{a}$ is the concentration of nutrients after replenishing overlying water $(0 \mathrm{mg} / \mathrm{L}$ in this study).

$n$ is the number of sampling.

$A$ is the water interfacing area of the sediment $\left(0.00785 \mathrm{~m}^{2}\right.$ in this study).

$t$ is the averaged sampling interval (day).

\section{Results and Discussion}

\subsection{Changes of $\mathrm{pH}, \mathrm{DO}$ and $\mathrm{COD}$}

The physical and chemical characteristics of sea sediment and water were measured during the $20 \mathrm{~d}$ incubation period (Table 1). It was observed that the $\mathrm{pH}$ of overlying water increased from 7.99 to 8.21 meanwhile sediment $\mathrm{pH}$ decreased from 7.58 to 6.9. The change of $\mathrm{pH}$ seemed to be due to the migration of some chemical species, that ammonium might be released from the sediment pores into the overlying water. This natural migration of that species turned $\mathrm{pH}$ lower in the slurry phase while overlying water $\mathrm{pH}$ value slightly increased. The DO concentration of the overlying water has decreased from $5.7 \mathrm{mg} / \mathrm{L}$ to $4.1 \mathrm{mg} / \mathrm{L}$, which means the oxygen depletion originating from the anaerobic sediment. The COD can be regarded as an important indicator of pollution level, indicating a full degree of chemical oxidation of organic matter involved in the sediment and water. It also represents the substance including organic compounds prohibiting biodegradation. The COD value slightly increased from $21.7 \mathrm{mg} / \mathrm{g}$
Table 1. Physical and Chemical Characteristics of the Water and Sediments

\begin{tabular}{lcc}
\hline Parameters & Sediment & Water \\
\hline $\mathrm{pH}$ & 7.58 & 7.99 \\
$\mathrm{DO}(\mathrm{mg} / \mathrm{L})$ & -- & 5.7 \\
$\mathrm{ORP}(\mathrm{mV})$ & -215.3 & +260.3 \\
$\mathrm{~T}-\mathrm{N}(\mathrm{mg} / \mathrm{L})$ & $2.80^{*}$ & 0.36 \\
$\mathrm{NH}_{4}{ }^{+}-\mathrm{N}(\mathrm{mg} / \mathrm{L})$ & $1.67^{*}$ & 0.14 \\
$\mathrm{NO}_{3}{ }^{-} \mathrm{N}(\mathrm{mg} / \mathrm{L})$ & $0.061^{*}$ & 0.052 \\
$\mathrm{COD}(\mathrm{mg} / \mathrm{L})$ & $21.7^{*}$ & 2.2 \\
$\mathrm{AVS}(\mathrm{mg} / \mathrm{g})$ & 0.088 & -- \\
$\mathrm{SO}_{4}{ }^{2-}(\mathrm{mM})$ & 10.1 & -- \\
$\mathrm{Fe}^{2+}(\mathrm{mM})$ & 0.40 & -- \\
$\mathrm{Fe}^{3+}(\mathrm{mM})$ & 0.56 & -- \\
\hline
\end{tabular}

*sediment unit $\mathrm{mg} / \mathrm{g}$

to $24.4 \mathrm{mg} / \mathrm{g}$.ds in sediment while overlying water COD value increased significantly from $2.2 \mathrm{mg} / \mathrm{L}$ to $7.2 \mathrm{mg} / \mathrm{L}$. Organic compounds including nitrogen species (may be ammonium) could transport across the sediment/water interface so as to contribute to rise of COD, which might be depending on the migration rate as will be mentioned later.

\subsection{Change of Sulfur and Iron Concentration in the Sediment}

Sulfur is widespread in the marine environment and is present in many different forms: sulfides $\left(\mathrm{S}^{2-}\right)$, elemental sulfur $\left(\mathrm{S}_{8}\right)$, polysulfides $\left(\mathrm{S}_{\mathrm{n}}{ }^{2-}\right)$, sulfite $\left(\mathrm{SO}_{3}{ }^{2-}\right)$, sulfate $\left(\mathrm{SO}_{4}{ }^{2-}\right)$, thiosulfate $\left(\mathrm{S}_{2} \mathrm{O}_{3}{ }^{2-}\right)$ and different organic sulfur compounds. It is very common that polluted sediment along with overlying water contains a high concentration of organic matter. That tells how COD is considerably high and ORP value is so negative like for instance, $-215.3 \mathrm{mV}$ in this case. This surroundings condition would become anoxic, thus resulting in the reduction of the oxidized forms of sulfur to $\mathrm{H}_{2} \mathrm{~S}$ or sulfides that are a measure of the reduced (anoxic) state of the sediment. $\mathrm{H}_{2} \mathrm{~S}$ is regarded as a predominant form generated out of sulfate by anaerobic respiration in the marine environment [30]. Furthermore, $\mathrm{H}_{2} \mathrm{~S}$ can react with $\mathrm{Fe}^{2+}$ and produce mineral $\mathrm{FeS}$ as well. AVS $\left(\mathrm{H}_{2} \mathrm{~S}\right.$ and $\left.\mathrm{FeS}\right)$, the most common form of reduced sulfur is often used as a key index for sediment characterization [29]. The overall reaction can be represented by the equation:

$$
\begin{aligned}
& \mathrm{CH}_{2} \mathrm{O}+1 / 2 \mathrm{SO}_{4}{ }^{2-}+\mathrm{H}^{+} \longrightarrow 1 / 2 \mathrm{H}_{2} \mathrm{~S}+\mathrm{CO}_{2}+\mathrm{H}_{2} \mathrm{O} \\
& \mathrm{SO}_{4}{ }^{2-}+4 \mathrm{H}_{2}+2 \mathrm{H}^{+} \longrightarrow \mathrm{H}_{2} \mathrm{~S}+4 \mathrm{H}_{2} \mathrm{O} \\
& \mathrm{Fe}^{2+}+\mathrm{H}_{2} \mathrm{~S} \longrightarrow \mathrm{FeS}+2 \mathrm{H}^{+}
\end{aligned}
$$

Where $\mathrm{CH}_{2} \mathrm{O}$ represents a generic form of organic matter as carbohydrate.

As shown in (Fig. 1), AVS concentration kept increasing from $0.088 \mathrm{mg} / \mathrm{g} . \mathrm{ds}$ to $0.12 \mathrm{mg} / \mathrm{g} . \mathrm{ds}, 35 \%$ increase in total. Accordingly, 


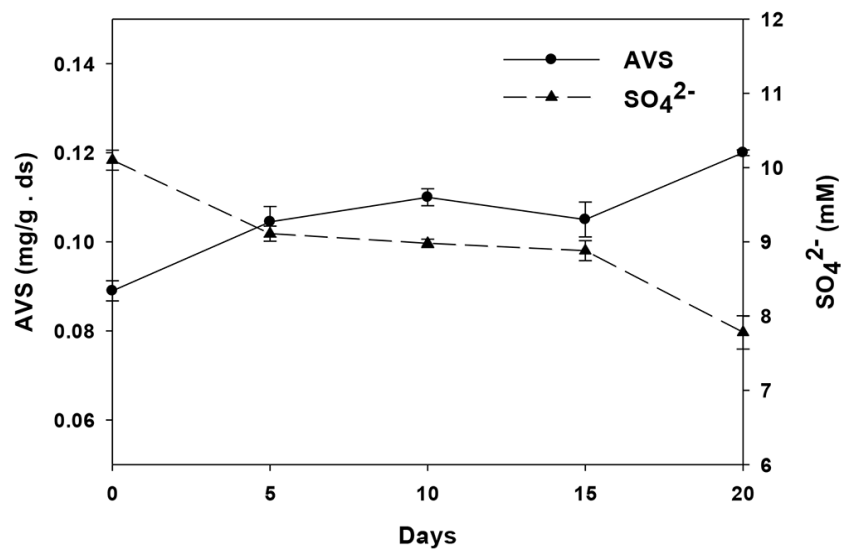

Fig. 1. Time evolution of acid volatile sulfide (AVS) and sulfate in the sediment.

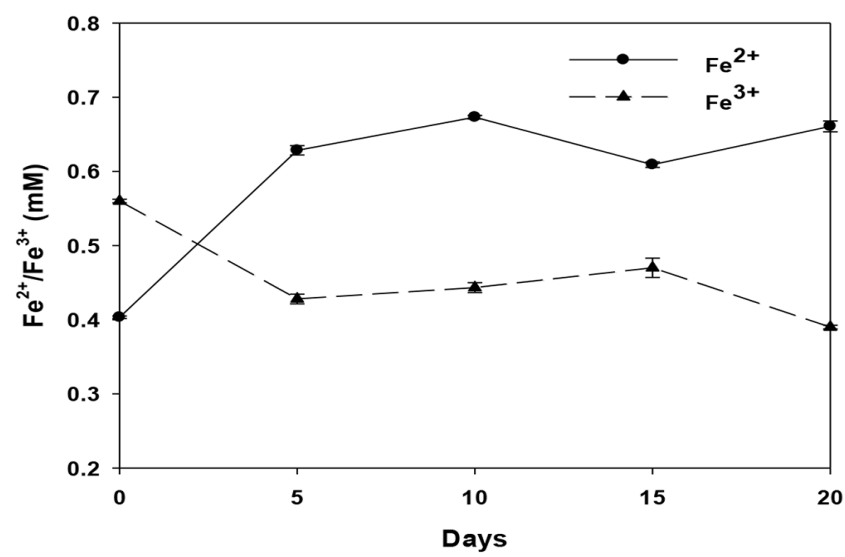

Fig. 2. Time evolution of $\mathrm{Fe}^{2+} / \mathrm{Fe}^{3+}$ concentrations in the sediment.

sulfate dropped to $7.8 \mathrm{mM}$ from $10.1 \mathrm{mM}$ (23\% decrease). The graph obviously dictates sulfate reduction through a complicated bio \& chemical pathway. Raise of acid volatile sulfide accelerated until the end of the experiment.

In an individual experiment, $\mathrm{Fe}^{3+}$ was determined as the difference between total extractable $\mathrm{Fe}$ and $\mathrm{Fe}^{2+}$. At the beginning concentrations of $\mathrm{Fe}^{3+}$ and $\mathrm{Fe}^{2+}$ were $0.56 \mathrm{mM}$ and $0.40 \mathrm{mM}$ in the sediment, respectively, which meant to be comparable with each other. The ferrous compound was reduced via electron acceptance to a ferric form as seen clearly in the plots of (Fig. 2). Note that despite of some error in mole numbers $\left(0.56 \mathrm{mM}\right.$ to $0.39 \mathrm{mM}$ for $\mathrm{Fe}^{3+}$; $0.40 \mathrm{mM}$ to $0.66 \mathrm{mM}$ for $\mathrm{Fe}^{2+}$ ) the rise and fall of the two species match fairly. The reduction of iron by sulfide leads to a release of $\mathrm{Fe}^{2+}$ into the sediment, which reflects the close mutual interaction between the sedimentary Fe and S cycle.

\subsection{Transition and Exchange among $\mathrm{T}-\mathrm{N}, \mathrm{NH}_{4}{ }^{+}-\mathrm{N}$ and $\mathrm{NO}_{3}^{-}-\mathrm{N}$ in the Sediment-Water System}

Nitrogen is one of the major parts of aquatic life in the marine environment. Reactive inorganic nitrogen like nitrate, nitrite, and ammonium are a dominant species in the marine environment where particulate matter accumulates in the sediment and is re-min- eralized, oxidized and eventually denitrified by a variety of microorganism. Nitrogen in the form of nitrate or ammonium, as a main moderating nutrient can be released from sediment into overlying water, which may have a serious impact on water quality and result in continuous eutrophication under certain environmental condition. The nitrogen and nitrogenous compounds in seawater and sediment are known to be controlled by many factors, for example, sediment type, the rate of sedimentation, redox condition, amount and type of organic matter, the intensity of mineralization of organic matter [31].

The transition and change of T-N, $\mathrm{NH}_{4}{ }^{+}-\mathrm{N}$, and $\mathrm{NO}_{3}{ }^{-}-\mathrm{N}$ concentrations in the whole system were monitored (Fig. 3-5). In spite of a little disturbance, T-N was measured as decreasing with time in the sediment whilst it soared (Fig. 3) up to $0.8 \mathrm{mg} / \mathrm{L}$, more than as twice as that of the starting value in the overlying waters. By comparing (Fig. 3 and 4), it was shown that half of the T-N may be organo-nitrogen. That indicates organic nitrogenous compounds were degrading over time in aid of existing microorganism, thus showing the decline of $\mathrm{T}-\mathrm{N}$ concentration in the sediment. A part of T-N could migrate across the sediment-water interface to the bulk water to increase the T-N content in the water column. Migration can be explained with that simple Fick's law where the transport at large counts on concentration gradient, but it is complicated in fact since the diffusional process should occur through so many bent, narrow, porous channels inside the sediment.

Likewise in (Fig. 3), the behavior of $\mathrm{NH}_{4}{ }^{+}-\mathrm{N}$ in the sediment and water were very similar as expected (Fig. 4). Sole difference in this plot is surplus production of $\mathrm{NH}_{4}{ }^{+}-\mathrm{N}$ in the sediment pores possibly with the DNRA process, an anaerobic respiration, where nitrate is reduced to nitrite and then ammonium. Ammonium overproduction would not be possible without DNRA because ammonia or ammonium in a highly reductive state could be denitrified easily by abundant denitrifying bacteria or so. The $\mathrm{NH}_{4}{ }^{+}-\mathrm{N}$ concentration in the sediment decreased from $1.67 \mathrm{mg} / \mathrm{g}$ to $1.29 \mathrm{mg} / \mathrm{g}$ while overlying water changed from $0.14 \mathrm{mg} / \mathrm{L}$ to $0.52 \mathrm{mg} / \mathrm{L}$.

Compared to T-N and $\mathrm{NH}_{4}{ }^{+}-\mathrm{N}, \mathrm{NO}_{3}{ }^{-}-\mathrm{N}$ concentrations in the system are not significant. However, the trend was totally different from the previous plots in that nitrate kept diminishing with time. In this case, we presume the oxidized form of nitrogen could be

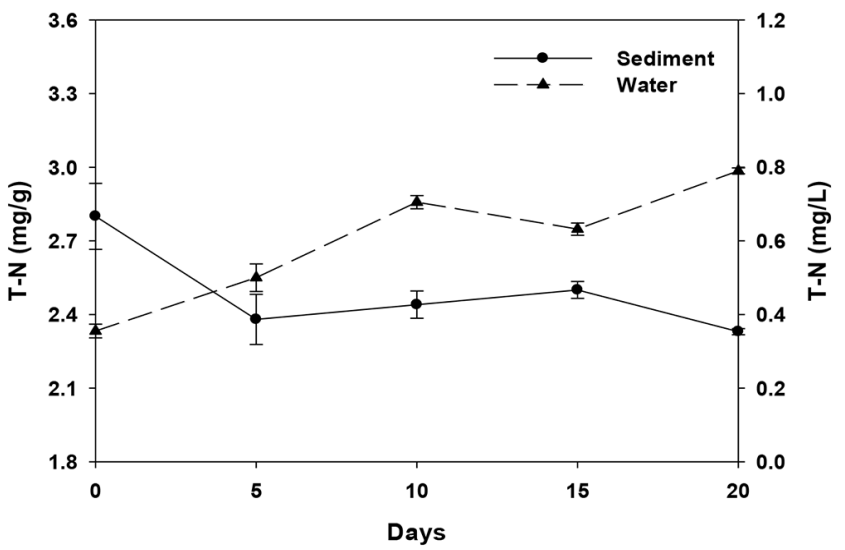

Fig. 3. Time evolution of total nitrogen (T-N) in the sediment and overlying water. 


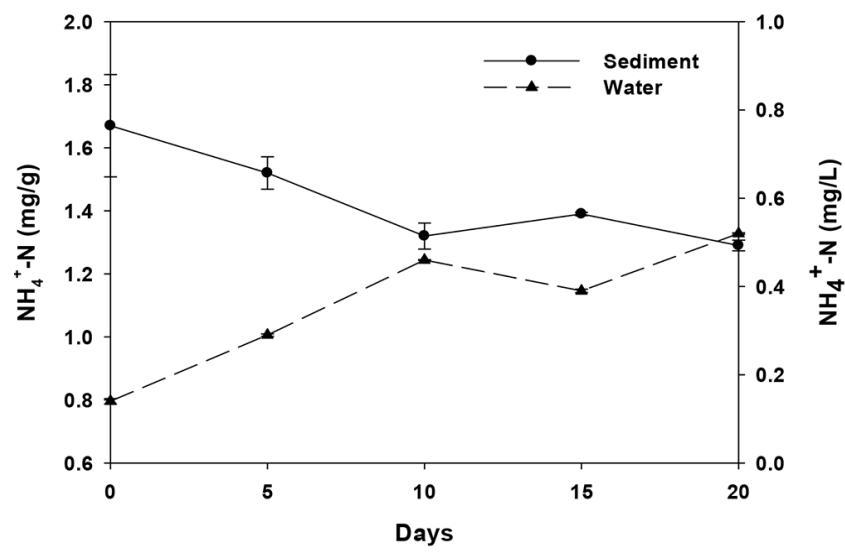

Fig. 4. Time evolution of $\mathrm{NH}_{4}{ }^{+}-\mathrm{N}$ in the sediment and overlying water.

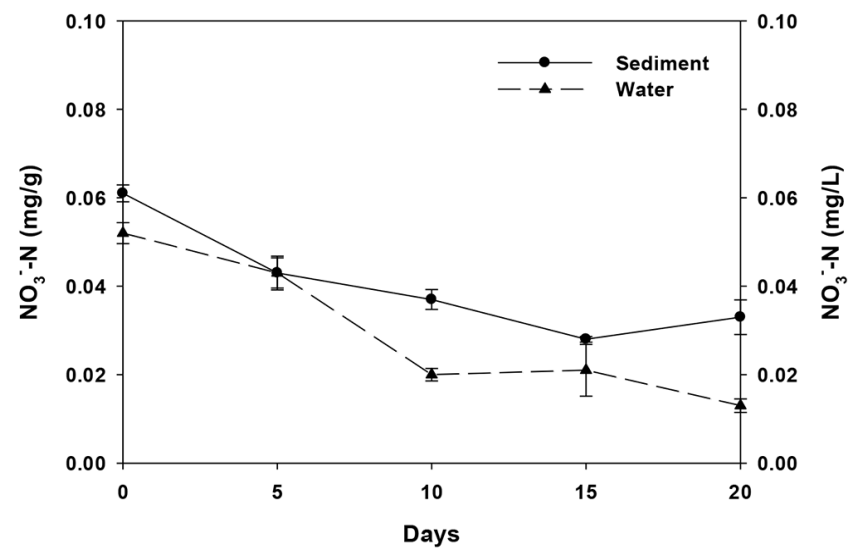

Fig. 5. Time evolution of $\mathrm{NO}_{3}{ }^{-} \mathrm{N}$ of the sediment and overlying water.

destined to be reduced under this oxygen depletion state. In the overlying water's disappearance of nitrate could be more accelerated with denitrifies that would convert nitrate into dinitrogen $\left(\mathrm{N}_{2}\right)$ eventually. On the other hand, $\mathrm{NO}_{2}^{-}-\mathrm{N}$ concentrations of the overlying water and sediment pore water (data not shown here) were observed to be very low concentration since nitrite is regarded as a common intermediate of denitrification and/or DNRA in the anoxic environment [32-33].

Experimental data suggests that oxidants like nitrate and sulfate greatly affect states of the interested species, particularly in the overlying waters by donating necessary electrons in the related redox reactions. DNRA is known to be activated in a carbon-rich environment by strictly anaerobic bacteria, i.e. sulfate-reducing bacteria $[34,35]$ which may be located close to the surface sediment under much-reduced conditions. DNRA and denitrification could be stimulated with the provision of those electrons while nitrate and sulfate are converted to ammonium and sulfides (or AVS) in the presence of ferric ions. The carbon source is essential to the activation of DNRA or denitrification but the limited amount of organic substance in this experiment (COD) might drive those metabolisms to be working somehow [36, 37]. In the further work, we try to propose a mechanistic model comprising diffusion theory and effects of governing environmental parameters in order to precisely describe nutrients distribution and migration. In reality, exchanges or migration of nutrients between water and sediment are highly complex, involving physical, biological and interrelated chemical processes [38, 39].

\subsection{Evaluation of Release Rates from Sediments to Water}

Nitrogen is a predominant compound in terms of its impact on biological activity and its migration between the bottom and water column. Nitrogen is more easily degraded than other compounds, thus the importance of the accumulation of organic matter, reflecting intense biological activity, with organic decomposition and nitrogen release into the overlying water predomination [24]. Nitrogenous
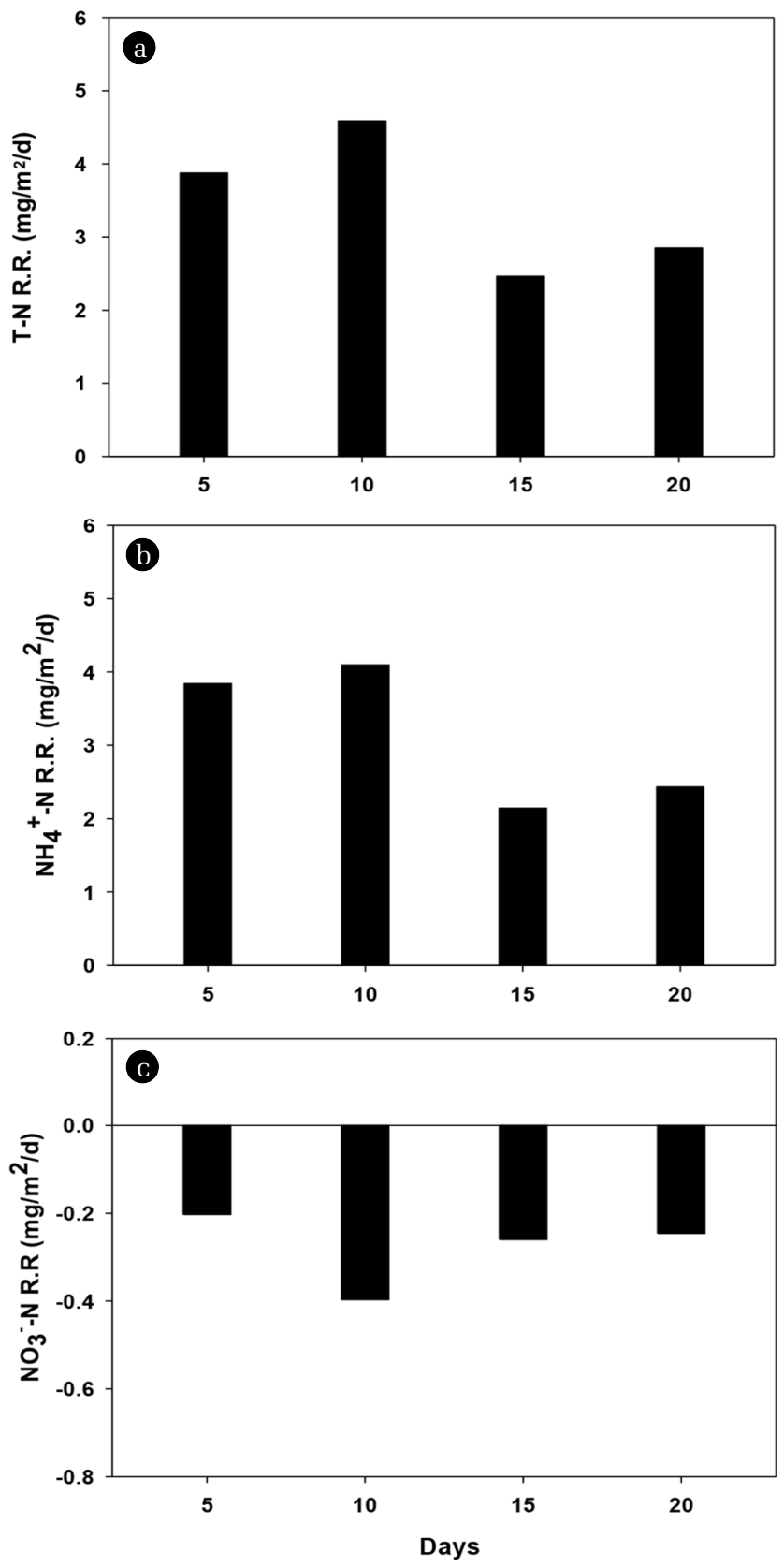

Fig. 6. Calculated release rates of (a) $\mathrm{T}-\mathrm{N}$, (b) $\mathrm{NH}_{4}{ }^{+}-\mathrm{N}$ and (c) $\mathrm{NO}_{3}-\mathrm{N}$ from sediments toward water. 
compounds can be released through the pore paths inside sediment toward water column by simple diffusion (depicted by Fick's law; flux is proportional to a concentration gradient) and microbial activation depending on the local environmental condition such as $\mathrm{pH}$, reduction state and temperature. Presuming a steady reduction state and a mild temperature and close-neutral $\mathrm{pH}$ for the microbial organism, diffusion, and physical hindrance could be a major limitation against releases of nitrogenous species. A simple calculation suggests about $50 \%$ of $\mathrm{T}-\mathrm{N}$ may be $\mathrm{NH}_{4}{ }^{+}-\mathrm{N}$. It was assume that, the rest would be organonitrogen which might keep being degraded under the current reductive condition. As shown in (Fig. 6), almost identical release rate around $3.8 \mathrm{mg} / \mathrm{m}^{2} / \mathrm{d}$ for both of T-N and $\mathrm{NH}_{4}{ }^{+}-\mathrm{N}$ initially. After that, the rate of $\mathrm{NH}_{4}{ }^{+} \mathrm{N}$ turned out to be lower than T-N probably because of surplus production of ammonium on the sediment side through DNRA. The final release rate for both nitrogenous species was close to 2.8 $\mathrm{mg} / \mathrm{m}^{2} / \mathrm{d}$. On the other hand, release rate for nitrate was found to be negative, which implied oxidation would prevail in the water phase rather than in the anaerobic sediment where reduction would dominate preferably.

\section{Conclusions}

Eutrophication in the marine environment has been a longtime issue in southern coastal areas of Korea. This study investigated the physicochemical characteristics and behavior of chemical substances, and related environmental variables using a lab-scale setup so as to simulate a system of sediment-overlying waters in a typical eutrophic region. Nitrogenous and sulfur species such as ammonium, nitrate, sulfate, and sulfide as key substance were analyzed along with basic environmental parameters such as $\mathrm{pH}$, ORP, and COD on the two phases. As a result, it was found that the T-N and nitrate concentrations in the sediment decreased sufficiently for DNRA to take place. The high concentration of ammonium in the sediment-water column exists used by sulfide as an electron donor in DNRA. Consequently, excess ammonium could be found in the sediment as well as in the overlying waters along with a consequence of diffusional release through prevailing pore water in the sediment. In addition, AVS (mostly $\mathrm{H}_{2} \mathrm{~S}$ and $\mathrm{FeS}$ ) increased more with increasing time, which thus confirmed the reduction of sulfate into sulfides under the highly anaerobic condition. T-N and $\mathrm{NH}_{4}{ }^{+}-\mathrm{N}$ showed a considerable rate of releases from the sediment to the water phase, around $4.5 \mathrm{mg} / \mathrm{m}^{2} / \mathrm{d}$ at maximum on $10^{\text {th }} \mathrm{d}$ and then reduced to less than $2.8 \mathrm{mg} / \mathrm{m}^{2} / \mathrm{d}$ on $20 \mathrm{~d}$ later, meanwhile nitrate seemed to diffuse back to the sediment from the subsurface of overlying waters, which might happen in a mild, oxic mood. This work can be progress in evaluating the inner eutrophication in terms of nitrogen, iron and sulfur compounds.

\section{Acknowledgments}

This research was supported by Basic Science Research Program through the National Research Foundation of Korea (NRF) funded by the Ministry of Science, ICT \& Future Planning (2017R1A 2B4008720) and BK21 plus program, South Korea. Also, it was partially supported by the combined undergraduate-graduate program of Soonchunhyang University (2017-2019).

\section{References}

1. Broggiato A, Arnaud-Haond S, Chiarolla C, Greiber T. Fair and equitable sharing of benefits from the utilization of marine genetic resources in areas beyond national jurisdiction: Bridging the gaps between science and policy. Mar. Policy 2014;49: 176-185.

2. Ferrol-Schulte D, Gorris P, Baitoningsih W, Adhuri DS, Ferse SCA. Coastal livelihood vulnerability to marine resource degradation: A review of the Indonesian national coastal and marine policy framework. Mar. Policy 2015;52:163-171.

3. MOF. Study on the total pollution loads management system in Masan Bay, a special management area and terrestrial pollution source management. Seoul: Ministry of Oceans and Fisheries; 2013.

4. Zhang Z, Lo IMC, Zheng G, Woon KS, Rao P. Effect of autotrophic denitrification on nitrate migration in sulfide-rich marine sediments. J. Soil. Sedi. 2015;15:1019-1028.

5. Wu FC, Qing HR, Wan GJ. Regeneration of N, P, and Si near the sediment/water interface of lakes from southwestern China plateau. Water Res. 2001;35:1334-1337.

6. Wu FC, Qing HR, Wan GJ, Tang DG, Huang RG, Cai YR. Geochemistry of $\mathrm{HCO}_{3}$ at the sediment-water interface of lakes from the southwestern Chinese plateau. Water Air Soil Pollut. 1997;99:381-390.

7. Bashkin V, Park S, Choi M, Lee C. Nitrogen budgets for the Republic of Korea and the Yellow Sea region. Biogeochemistry 2002;57:387-403.

8. Lim H-S, Diaz RJ, Hong J-S, Schaffner LC. Hypoxia and benthic community recovery in Korean coastal waters. Mar. Pollut. Bull. 2006;52:1517-1526

9. Capriulo GM, Smith G, Troy R, Wikfors G, Pellet J, Yarish C. The planktonic food web structure of a temperate zone estuary, and its alteration due to eutrophication. Hydrobiologia 2002;475-476:263-333.

10. Schramm W, Lotze H, Schories D. Eutrophication and macroalgal blooms in inshore waters of the German Baltic coasts: The Schlei Fjord, a case study. In: Rijstenbil JW, Kamermans P, Nienhuis PH, eds. EUMAC Synthesis Report and Proceedings of the second EUMAC Workshop, Sete, France; 1996. p.18-73.

11. Schumacher J, Dolch T, Reise K. Transitions in sandflat biota since the 1930s: Effects of sea-level rise, eutrophication and biological globalization in the tidal bay Konigshafen, northern Wadden Sea. Helgoland Mar. Res. 2014;68:289-298.

12. Haque N, Kwon SH. Nutrients dynamics study of overlying water affected by peroxide-treated sediment. J. Ecol. Environ. 2017;41:32.

13. Liu B, Wang WL, Han RM, et al. Dynamics of dissolved oxygen and the affecting factors in sediment of polluted urban rivers under aeration treatment. Water Air Soil Pollut. 2016;227:172.

14. Havens KE, Fukushima T, Xie P, et al. Nutrient dynamics and the eutrophication of shallow lakes Kasumigaura (Japan), Donghu (PR China), and Okeechobee (USA). Environ. Pollut. 
2001;111:263-272.

15. Li B, Zhang K, Zhong BC, Wang DZ. An experimental study on release of pollutants from sediment under hydrodynamic conditions. Chinese J. Hydrodyn. 2008;23:126-133.

16. Ignatieva NV. Nutrient exchange across the sediment-water interface in the eastern Gulf of Finland. Boreal Environ. Res. 1999;4:295-305.

17. Liikanen A, Martikainen PJ. Effect of ammonium and oxygen on methane and nitrous oxide fluxes across sediment-water interface in a eutrophic lake. Chemosphere 2003;52:1287-1293.

18. Rickard D, Morse JW. Acid volatile sulfide (AVS). Mar. Chem. 2005;97:141-197.

19. Wu H, Huo Y, Zhang J, Liu Y, Zhao Y, He P. Bioremediation efficiency of the largest scale artificial Porphyra yezoensis cultivation in the open sea in China. Mar. Pollut. Bull. 2015;95:289-296.

20. libert PM, Burkholder JM. Harmful algal blooms and eutrophication: "Strategies" for nutrient uptake and growth outside the Redfield comfort zone. Chinese J. Oceanol. Limnol. 2011;29: 724-738.

21. Nagasoe S, Shikata T, Yamasaki Y, et al. Effects of nutrients on growth of the red-tide dinoflagellate Gyrodinium instriatum Freudenthal et Lee and a possible link to blooms of this species. Hydrobiologia 2010;651:225-238.

22. Carpenter SR, Caraco NF, Correll DL, Howarth RW, Sharpley AN, Smith VH. Nonpoint pollution of surface waters with phosphorus and nitrogen. Ecol. Applic. 1998;8:559-568.

23. Arega F, Lee JHW. Diffusional mass transfer at sediment-water interface of cylindrical sediment oxygen demand chamber. J. Environ. Eng. 2005;131:755-766.

24. Hou D, He J, Lü C, Sun Y, Zhang F, Otgonbayar K. Effects of environmental factors on nutrients release at sediment-water interface and assessment of trophic status for a typical shallow lake, Northwest China. Sci. World J. 2013;3:716342.

25. Ministry of land, transport and maritime affairs. Standard method for the examination of sea water and sediment. Sejong: Ministry of land, transport and maritime affairs: South Korea; 2010.

26. Stookey LL. Ferrozine-A new spectrophotometric reagent for iron. Anal. Chem. 1970;42:779-781.

27. Viollier E, Inglett PW, Hunter K, Roychoudhury AN, Van Cappellen P. The ferrozine method revisited: Fe(II)/Fe(III) deter- mination in natural waters. Appl. Geochem. 2000;15:785-790.

28. Hieltjes AH, Lijklema L. Fractionation of inorganic phosphates in calcareous sediments. J. Environ. Qual. 1980;9:405-407.

29. Kwon SH, Cho D, Jiang S. Chemical and biological analysis of bay sediment where magnesium oxide compounds are applied. Environ. Eng. Res. 2014;19:101-105.

30. Canfield DE, Thamdrup B, Hansen JW. The anaerobic degradation of organic matter in Danish coastal sediments: Iron reduction, manganese reduction, and sulfate reduction. Geochim. Cosmochim. Acta 1993;57:3867-3883.

31. Xiang S-L, Zhou W-B. Phosphorus forms and distribution in the sediments of Poyang Lake, China. Int. J. Sediment Res. 2011;26:230-238.

32. Wu Q, Zhang R, Huang S, Zhang H. Effects of bacteria on nitrogen and phosphorus release from river sediment. J. Environ. Sci. 2008;20:404-412.

33. Koike I, Sørensen J. Nitrate reduction and denitrification in marine sediments. In: Blackburn TH, Sørensen J, eds. Nitrogen cycling in coastal marine environments. New York: John Wiley \& Sons Ltd.; 1988.

34. Christensen PB, Rysgaard S, Sloth NP, Dalsgaard T, Schwaerter S. Sediment mineralization, nutrient fluxes, denitrification and DNRA in an estuarine fjord with sea cage trout farms. Aquat. Microb. Ecol. 2000;21:73-84.

35. Tiedje JM. Ecology of denitrification and dissimilatory nitrate reduction to ammonium. In: Zehnder AJB, ed. Biology of anaerobic microorganisms. New York: John Wiley \& Sons Ltd.; 1988. p. $179-244$.

36. Boström B, Andersen JM, Fleischer S, Jansson M. Exchange of phosphorus across the sediment water interface. Hydrobiologia 1988;170:229-244.

37. Jørgensen KS. Annual pattern of denitrification and nitrate ammonification in estuarine sediment. Appl. Environ. Microbiol. 1989;55:1841-1847

38. Clavero V, Izquierdo JJ, Palomo L, Fernández JA, Niell FX. Water management and climate changes increases the phosphorus accumulation in the small shallow estuary of the Palmones River (Southern Spain). Sci. Total Environ. 1999;228:193-202.

39. Gao JQ, Xiong ZT, Zhang JD, Zhang WH, Mba FC. Phosphorus removal from water of eutrophic Lake Donghu by five submerged macrophytes. Desalination 2009;242:193-204. 